Article

\title{
Characterizing the Energy-Saving Behaviors, Attitudes and Awareness of University Students in Macau
}

\author{
Shujie Zhao ${ }^{1}$, Qingbin Song ${ }^{1, *}$ and Chao Wang ${ }^{2}$ \\ 1 Macau Environmental Research Institute, Macau University of Science and Technology, Macau 999078, \\ China; 1709853dem20001@student.must.edu.mo \\ 2 Guangdong Provincial Key Laboratory on Functional Soft Condensed Matter, School of Materials and \\ Energy, Guangdong University of Technology, Guangzhou 510006, China; chaowang@gdut.edu.cn \\ * Correspondence: qbsong@must.edu.mo
}

Received: 9 September 2019; Accepted: 10 November 2019; Published: 12 November 2019

\begin{abstract}
Currently, energy and its usage are the primary environmental issues in all countries and regions. As a special social group, university students not only have extremely high energy consumption needs, but they have more advanced consumption concepts. Understanding their energy-saving characteristics could provide foresight for predicting the energy-saving characteristics of future residents. Using data collected from 737 valid questionnaires, from five typical universities in Macau, this study investigated university students' energy-saving behaviors, attitudes and awareness, and analyzed the possible influencing factors. The results showed that the energy-saving behaviors and attitudes of respondents from five university were nearly the same. Meanwhile, $75.98 \%$ of the respondents clearly recognized that energy-savings behaviors are closely related to their daily study and life, and $96.61 \%$ of the university students thought that it is very necessary to save energy. In addition, $92.94 \%$ of students thought it was necessary to carry out energy-saving education in universities. The regression analysis indicated that "the relationship between energy-saving awareness and daily life" and "the necessity of energy-saving education" are positively correlated with the energy-saving awareness at the significance level of $1 \%$, whereas the energy-saving behaviors, "give priority to energy-saving products" and "shut down your computer when going out", are positively correlated with energy-saving awareness at the significance level of $10 \%$ and $5 \%$, respectively. Finally, we proposed effective suggestions for raising the awareness of saving energy among university students.
\end{abstract}

Keywords: energy-saving awareness; behavior and attitude; questionnaire survey; university student; Macau

\section{Introduction}

Energy is essential and important to the economic and social development and the improvement of quality of life in all countries and regions [1]. Currently, the largest percentage of energy consumption is derived from conventional or non-renewable energy resources such as coal, oil, and natural gas, while their energy-related emissions contribute to approximately $80 \%$ of the greenhouse gas emissions of the EU [2]. Since 1973, Asia's coal and oil consumption have grown from 185 to 877 million tons of oil equivalent (Mtoe), and from 105 to 950 Mtoe, respectively. Asia's total electricity generation has grown a staggering 26 -fold, with annual growth rates from $6.5 \%$ to $9 \%$ as compared with a global growth rate of $2.2 \%$ [3]. At present, Asia accounts for $36 \%$ of the global energy consumption, and in the future, total energy consumption in Asia is expected to increase by 2.2-fold from 2008 to 2035 [4]. In non-OECD Asian countries, the energy consumption levels from the industrial and residential 
sectors are expected to increase by 1.9-fold and 2.2-fold, respectively, while their expected growth worldwide is only 1.5-fold and 1.3-fold, respectively [5].

Recently, more and more scholars recognize the importance of reducing energy consumption in terms of people's energy-saving awareness and behavioral perspective [6]. Energy consumption of university students is determined by energy-saving awareness and other factors, which is more difficult to regulate than other energy consumption departments, but more efficient. In order to reduce energy consumption, understanding the correlation between energy-saving awareness and other factors is the basis of exploring the formation of individual energy-saving behaviors. Existing studies have used the survey data in specific cities or regions to reveal the impact of internal influence factors (such as demographic variables, values, and energy knowledge) and external influence factors (such as social norms and policies) on energy-saving behavior. For example, Kang et al. [7] investigated the influence of internal influencing factors (such as energy-saving awareness and knowledge) on residents' energy-saving behaviors. Wang et al. [8] believed that energy knowledge has an indirect impact on residents' intention to save energy. Poortinga et al. [9] found that there was a significant correlation between education level and energy-saving behavior. Yu et al. [10] found that residents' income level had a significant impact on the purchase and use of energy-saving household appliances. Yue et al. [11] believed that social norms and other situational factors had a significantly positive effect on energy-saving behaviors. Ertz et al. [12] investigated the direct impact of situational factors, such as perceived ability, on energy-saving behaviors, and the indirect impact of attitude variables, such as values, beliefs, and norms.

Currently, most studies have focused on residents' energy-saving behaviors, and there is still a lack of systematic researches on energy-saving behavior and awareness of university students. As the future generation, university students not only have extremely high energy consumption needs, but they have more advanced consumption concepts. At the same time, understanding the energy-saving characteristics of university students could provide an important reference for predicting future residents' energy-saving awareness [13]. Some studies show that several factors affect energy use behavior and awareness of university students. For example, ethics, various incentives and obstacles, energy-saving awareness and attitudes, as well as regulations and policies are considered to be important influencing factors [14,15]. Energy-saving behavior is also closely related to environmental attitudes, which are related to social norms and social influences [16]. According to Vringer et al. [17], inability, unwillingness, and social problems were regarded as the main obstacles to individuals' energy-saving behaviors. It has also been reported that even without financial rewards, group-level influences and peer education led to some changes in individual behavior [18]. Although these influencing factors have been identified in many studies, the relationship between these influencing factors and energy-saving awareness of university students has received little attention. Therefore, in order to fully consider the influence of various factors, for this study we selected university students in Macau as an example to reveal the relationship between various influencing factors and university students' energy-saving awareness.

The Macau Special Administrative Region (SAR) of China is situated on the west side of the Pearl River Delta, on the southeastern coast of China. With an area of just 32.8 square kilometers, Macau's population has increased by $49 \%$, from 0.43 million in 2000 to 0.63 million in 2018. The GDP per capita in Macau grew at an annual rate of about 10.04\% from 2000 (15,659 U.S. dollars) to 2018 (86,355 U.S. dollars) [19]. Economic growth and improvements in living standards have led to higher household energy demand and consumption [20]. In Macau, energy consumption has steadily increased from 16,295 tera-joule (TJ) in 1990 to 34,612 TJ in 2015. The energy consumption of residential buildings has increased from $228.70 \mathrm{MJ} / \mathrm{m}^{2} /$ year in 2007 to $264.97 \mathrm{MJ} / \mathrm{m}^{2} /$ year in 2016 [21].

At present, Macau's energy-saving policies are mainly focused on advanced energy-saving technologies (such as subsidies for the purchase of energy-saving appliances and alternative-fuel vehicles). However, this technical approach is widely believed to require a lot of time and money, and in fact, changing habits can be more effective without additional investment [22]. For the university 
students in Macau, it still needs to be clarified whether these factors have any influences, in what ways, and whether there are spatial differences among the different universities in Macau. This study aims to investigate university students' energy-saving behaviors, attitudes, and awareness, as well as identify their possible influence factors, and further put forward effective suggestions for improving university students' energy-saving behaviors and awareness.

\section{Methodology}

\subsection{Survey Design}

The questionnaire used in this study is divided into four parts with a total of 23 questions. The first part includes general questions to measure university students' energy-saving knowledge and understandings. The second section includes questions designed to reveal the energy-saving awareness, energy-saving attitudes, energy-saving education, and energy-saving behaviors of university students. The third part describes renewable energy options and attitudes. The final part of the questionnaire collects some basic information about the respondents (including gender, major, grade, and household register).

For this questionnaire design, a pretest survey $(n=20)$ was conducted prior to the final university student survey to assess the validity of the questionnaire and identify unresolved issues [23,24]. The content of the questionnaire was modified based on feedback prior to testing.

The questionnaire used, in this study, considered five possible influence factors of energy-saving awareness, which included student basic information, energy-saving knowledge or cognition, environmental education, energy-saving attitudes, and energy-saving behaviors.

In this study, the five primary universities in Macau, which are the Macau University, the Macau University of Science and Technology, the Macau City University, the Macau Polytechnic Institute, and the Macau Tourism Institute, were selected as the research objects, which contribute to more than $90 \%$ of the university students in Macau.

\subsection{Sample Size and Distribution}

The survey was conducted in January 2019 at five universities (the Macau University, the Macau University of Science and Technology, the Macau City University, the Macau Polytechnic Institute, and the Macau Tourism Institute). On the basis of our previous research experiences [23,24], the questionnaires were distributed to 800 university students through field research and 160 questionnaires were required from each university. It is worth noting that from the 800 questionnaires distributed to students those included in this study consisted of questionnaires from students who answered questions, and questionnaires with no responses did not appear in our statistics. Finally, a total of 737 valid questionnaires were screened in this survey, with an effective rate of $92 \%$, as shown in Table 1 .

Table 1. Distribution of questionnaires.

\begin{tabular}{ccccccc}
\hline Region & $\begin{array}{c}\text { Macau } \\
\text { University }\end{array}$ & $\begin{array}{c}\text { Macau } \\
\text { University of } \\
\text { Science and } \\
\text { Technology }\end{array}$ & $\begin{array}{c}\text { Macau City } \\
\text { University }\end{array}$ & $\begin{array}{c}\text { Macau } \\
\text { Polytechnic } \\
\text { Institute }\end{array}$ & $\begin{array}{c}\text { Macau } \\
\text { Tourism } \\
\text { Institute }\end{array}$ & Total \\
Sample size & 160 & 160 & 160 & 160 & 160 & 800 \\
Valid sample & 152 & 151 & 146 & 148 & 140 & 737 \\
Valid recovery rates & $95.00 \%$ & $94.38 \%$ & $91.25 \%$ & $92.5 \%$ & $87.50 \%$ & $92.13 \%$ \\
\hline
\end{tabular}

\subsection{Survey Methods}

Paper questionnaire sampling was adopted in the survey because this method has been found to provide the most complete, comprehensive, and meaningful results [25]. The research team consisted of 10 trained graduate students from the Macau University of Science and Technology, who were 
familiar with Macau and all kinds of information required for investigation, as well as able to effectively and continuously deal with various situations in a rigorous investigation. It is worth mentioning that paper questionnaire sampling largely avoids collecting wrong or unrealistic answers [26].

\subsection{Data Analysis}

According to previous studies [27-29], energy-saving awareness can be influenced by factors, such as "basic information, energy-saving knowledge or cognition, environmental education, energy-saving attitudes, and energy-saving behaviors". Therefore, we set up the equation to quantify these possible potential relationships. To acquire the necessary data to assess the influence factor of energy-saving awareness of Macau students, this study used the "Fisher" discriminant analysis method of multivariate statistics and established the discriminant function according to the specific criteria. Then the regression model was used to identify the potential relationship between the respondent's social characteristics and energy-saving awareness. It assumes that the equation defining the energy-saving awareness contains a series of independent variables. Therefore, we used energy-saving awareness as a dependent variable, and the equation is as follows:

$$
\mathrm{y}=\beta_{0}+\sum \beta_{1} x_{1}+\sum \beta_{2} x_{2}+\sum \beta_{3} x_{3}+\sum \beta_{4} x_{4}+\sum \beta_{5} x_{5}+\mu
$$

where $y$ indicates the respondent's energy-saving awareness (here, the energy awareness were obtained through the question "How do you think about energy-saving?", shown in Table 3); $x_{1-5}$ represents a set of respondent's social characteristics (including basic information, energy-saving knowledge, energy-saving education, energy-saving attitudes, and energy-saving behaviors); $\beta_{1-5}$ indicates the corresponding vector of undetermined coefficients; $\beta_{0}$ is a constant term; and $\mu$ is the random variable of the error term.

On the basis of the literature reviews described above and an analysis based on grounded theory, the following hypotheses were proposed:

- $X_{1}$ represents basic information. Energy-saving awareness varies with different gender $\left(X_{11}\right)$, grade $\left(X_{12}\right)$, and household registration $\left(X_{13}\right)$.

- $\mathrm{X}_{2}$ represents energy-saving knowledge, including the relationship between energy-saving and life $\left(\mathrm{X}_{21}\right)$, the concept of renewable energy $\left(\mathrm{X}_{22}\right)$, and the necessity of renewable energy development $\left(\mathrm{X}_{23}\right)$.

- $\quad X_{3}$ represents energy-saving education. Energy-saving education is mainly embodied in energy-saving activities $\left(X_{31}\right)$ and energy-saving publicity $\left(X_{32}\right)$.

- $\quad \mathrm{X}_{4}$ represents energy-saving attitudes, including the necessity of energy-saving education $\left(\mathrm{X}_{41}\right)$.

- $X_{5}$ represents energy-saving behaviors. Energy-saving behaviors are mainly divided into green purchase behaviors and use-reduction behaviors, such as buying energy-saving products $\left(X_{51}\right)$, turning off the lights when going out $\left(\mathrm{X}_{52}\right)$, turning off the air conditioner when going out $\left(\mathrm{X}_{53}\right)$, turning off the computer when going out $\left(\mathrm{X}_{54}\right)$, and cutting off the power during holidays $\left(\mathrm{X}_{55}\right)$.

\section{Results}

\subsection{Descriptive Statistics}

\subsubsection{Sociodemographic Characteristics}

Table 2 presents the descriptive statistics of respondents' basic information which included gender, major, grade, and household register. In terms of gender, there were 345 males and 392 females. With respect to students' majors, we observed that $41.25 \%$ of students majored in business-related courses, followed by humanities and arts $(20.62 \%)$, and science $(19.40 \%)$. Among them, undergraduate students accounted for $70.14 \%$ of all the respondents, followed by $25.92 \%$ master's and $3.93 \%$ doctoral students. In this survey, $22.25 \%$ of respondents were local residents of Macau, and $77.75 \%$ were 
non-local residents of Macau (from mainland China, other countries or regions). All basic information of the respondents is close to the average data on the university students.

Table 2. Basic information of the surveyed respondents.

\begin{tabular}{ccccc}
\hline Basic Information & Group & Population & Proportion & Description \\
\hline Gender & Men & 345 & $46.81 \%$ & 0 \\
$\left(\mathrm{X}_{11}\right)$ & Women & 392 & $53.19 \%$ & 1 \\
\hline & Humanities and art & 152 & $20.62 \%$ & $\#$ \\
& Law & 61 & $8.28 \%$ & $\#$ \\
Major & Business & 304 & $41.25 \%$ & $\#$ \\
& Computer & & & \\
& communication & 18 & $2.44 \%$ & $\#$ \\
& technology & & & $\#$ \\
& Engineering & 59 & $8.01 \%$ & $\#$ \\
\hline \multirow{5}{*}{ Grade } & Science & 143 & $19.40 \%$ & 1 \\
$\left(\mathrm{X}_{12}\right)$ & Freshman & 134 & $18.18 \%$ & 3 \\
& Sophomore & 134 & $18.18 \%$ & 4 \\
& Junior & 152 & $20.62 \%$ & 5 \\
& Senior & 97 & $13.16 \%$ & 6 \\
\hline Household register & Master & 191 & $25.92 \%$ & 0 \\
$\left(\mathrm{X}_{13}\right)$ & Doctor & 29 & $3.93 \%$ & 1 \\
\hline
\end{tabular}

\# represents no description.

\subsubsection{Knowledge and Concept of Saving Energy}

This section aims to investigate the knowledge and concept of saving energy among university students in Macau. According to our survey, students have a relatively high awareness of saving energy and environmental protection. As shown in Table 3,96.61\% of the university students believed that saving energy is very necessary in order to protect the environment, only $3.39 \%$ of the university students thought that there was no need to save energy because they have paid for energy consumption, and $75.98 \%$ of the respondents clearly realized that saving energy is closely related to our daily life and study. In terms of the development of renewable energy, $94.85 \%$ of university students know about renewable energy mainly through the Internet, and $98.37 \%$ think it is necessary to develop renewable energy in Macau. Because sunshine in Macau is relatively stable and of good quality, students generally believe that solar energy should be given priority, followed by wind and tidal energy.

As shown in Table 4, only $6.38 \%$ of the students participate often in energy-saving activities, and $21.03 \%$ of the students have never participated in any energy-saving activities. In terms of energy-saving publicity, $67.70 \%$ of the students believe that the university has carried out energy-saving publicity, and only $3.80 \%$ of the students believe that there are no publicity activities at their university. Among the five universities, the Macau University of Science and Technology has the most frequent energy-saving publicity, and the number of students who have participated in energy-saving education ranks first among the five universities.

\subsubsection{Energy-Saving Attitudes}

This section mainly investigates the energy-saving attitudes of the university students. Table 5 presents the necessity of energy-saving education and the most easily accepted education mode. We identified that $92.94 \%$ of students think that it is necessary to carry out energy-saving activities and environmental protection education in universities, among which $38.67 \%$ think it is very necessary. In terms of education methods, people are most willing to carry out corresponding 
energy-saving activities (52.37\%), followed by news media (27\%), classroom lectures $(12.75 \%)$, and reading energy-saving books $(7.87 \%)$. In the five universities, students' attitudes toward saving energy were almost identical, and they generally tended to participate in energy-saving activities.

Table 3. Perception of saving energy among Macau university students.

\begin{tabular}{|c|c|c|c|c|}
\hline Item & Questions & Answer & Proportion & Description \\
\hline \multirow{3}{*}{1} & How do you think about & No need to save & $3.39 \%$ & 1 \\
\hline & saving energy? & Appropriate to save & $70.42 \%$ & 2 \\
\hline & (y) & Save whatever you can & $26.19 \%$ & 3 \\
\hline \multirow{3}{*}{2} & \multirow{3}{*}{$\begin{array}{l}\text { The relationship between } \\
\text { energy-saving awareness } \\
\text { and daily life } \\
\left(\mathrm{X}_{21}\right)\end{array}$} & No relationship at all & $2.85 \%$ & 1 \\
\hline & & A little bit related & $21.17 \%$ & 2 \\
\hline & & Closely related & $75.98 \%$ & 3 \\
\hline \multirow{5}{*}{3} & \multirow{5}{*}{$\begin{array}{l}\text { Do you understand the } \\
\text { concept of renewable } \\
\text { energy? } \\
\left(\mathrm{X}_{22}\right)\end{array}$} & Absolutely not & $0.41 \%$ & 1 \\
\hline & & Don't understand & $4.75 \%$ & 2 \\
\hline & & General & $38.94 \%$ & 3 \\
\hline & & Understand & $41.66 \%$ & 4 \\
\hline & & Very understand & $14.25 \%$ & 5 \\
\hline \multirow{5}{*}{4} & \multirow{5}{*}{$\begin{array}{c}\text { Do you think it is necessary } \\
\text { to develop renewable } \\
\text { energy? } \\
\left(\mathrm{X}_{23}\right)\end{array}$} & Not at all & $0.41 \%$ & 1 \\
\hline & & Unnecessary & $1.22 \%$ & 2 \\
\hline & & General & $13.16 \%$ & 3 \\
\hline & & Necessary & $49.66 \%$ & 4 \\
\hline & & Quite necessary & $35.55 \%$ & 5 \\
\hline
\end{tabular}

Table 4. Energy-saving education.

\begin{tabular}{ccccc}
\hline Item & Questions & Answer & Proportion & Description \\
\hline \multirow{3}{*}{$\mathbf{1}$} & Have you participated in & Never & $21.03 \%$ & 1 \\
& energy-saving activities? & Rarely & $40.43 \%$ & 2 \\
& $\left(\mathrm{X}_{31}\right)$ & Sometimes & $32.16 \%$ & 3 \\
& & Often & $6.38 \%$ & 4 \\
\hline \multirow{2}{*}{$\mathbf{2}$} & Does your university ever & Never & $3.80 \%$ & 1 \\
& carry out energy-saving & Rarely & $28.49 \%$ & 2 \\
& publicity? & Sometimes & $45.18 \%$ & 3 \\
& $\left(\mathrm{X}_{32}\right)$ & Often & $22.52 \%$ & 4 \\
\hline
\end{tabular}

Table 5. Energy-saving attitudes.

\begin{tabular}{ccccc}
\hline Item & Questions & Answer & Proportion & Description \\
\hline & & Unnecessary & $0.41 \%$ & 1 \\
\multirow{2}{*}{$\mathbf{1}$} & The necessity of & Dispensable & $6.65 \%$ & 2 \\
& energy-saving education? & Necessary & $54.27 \%$ & 3 \\
& $\left(\mathrm{X}_{41}\right)$ & Quite necessary & $38.67 \%$ & 4 \\
\hline \multirow{4}{*}{$\mathbf{2}$} & Energy-saving education & Reading energy-saving books & $7.87 \%$ & $\#$ \\
& mode & Classroom lectures & $12.75 \%$ & $\#$ \\
& & News media & $27.00 \%$ & $\#$ \\
& & Energy-saving activities & $52.37 \%$ & $\#$ \\
\hline
\end{tabular}

\# represents no description.

\subsubsection{Energy-Saving Behaviors and Attitudes}

Table 6 summarizes the energy-saving behaviors of respondents. It can be seen that $24.83 \%$ of respondents frequently gave priority to purchasing green and energy-saving products. Therefore, 
the establishment of clear energy-saving signs is essential to promote energy-saving behaviors and environmental protection in Macau. In terms of methods of travel, $62.28 \%$ of respondents choose to travel by bus and $21.85 \%$ choose to walk. This is more proof that the respondents respond to the call for green travel with practical actions.

Table 6. Respondents' energy-saving behaviors.

\begin{tabular}{|c|c|c|c|c|}
\hline Item & Questions & Answer & Proportion & Description \\
\hline \multirow{5}{*}{1} & \multirow{5}{*}{$\begin{array}{c}\text { Have green energy-efficient } \\
\text { products given priority } \\
\text { when shopping? } \\
\left(X_{51}\right)\end{array}$} & Certainly not & $0.81 \%$ & 1 \\
\hline & & Won't consider & $5.97 \%$ & 2 \\
\hline & & Don't care & $18.32 \%$ & 3 \\
\hline & & Sometimes & $50.07 \%$ & 4 \\
\hline & & Often & $24.83 \%$ & 5 \\
\hline \multirow{4}{*}{2} & \multirow{4}{*}{$\begin{array}{l}\text { Would you turn off the lights } \\
\text { when going out? } \\
\qquad\left(\mathrm{X}_{52}\right)\end{array}$} & Never & $0.95 \%$ & 1 \\
\hline & & Generally not & $4.21 \%$ & 2 \\
\hline & & Remember & $17.10 \%$ & 3 \\
\hline & & Must & $77.75 \%$ & 4 \\
\hline \multirow{4}{*}{3} & \multirow{4}{*}{$\begin{array}{c}\text { Would you turn off the air } \\
\text { conditioning in your } \\
\text { dormitory when going out? } \\
\left(\mathrm{X}_{53}\right)\end{array}$} & Never & $1.90 \%$ & 1 \\
\hline & & Generally not & $3.12 \%$ & 2 \\
\hline & & Remember & $12.35 \%$ & 3 \\
\hline & & Must & $82.63 \%$ & 4 \\
\hline \multirow{4}{*}{4} & \multirow{4}{*}{$\begin{array}{l}\text { Would you shut down your } \\
\text { computer when going out } \\
\qquad\left(\mathrm{X}_{54}\right)\end{array}$} & Never & $1.90 \%$ & 1 \\
\hline & & Generally not & $15.20 \%$ & 2 \\
\hline & & Remember & $21.44 \%$ & 3 \\
\hline & & Must & $61.47 \%$ & 4 \\
\hline \multirow{4}{*}{5} & \multirow{4}{*}{$\begin{array}{c}\text { Would you cut off the } \\
\text { dormitory power before } \\
\text { leaving school on holidays? } \\
\left(X_{55}\right)\end{array}$} & Never & $1.63 \%$ & 1 \\
\hline & & Generally not & $8.41 \%$ & 2 \\
\hline & & Remember & $18.05 \%$ & 3 \\
\hline & & Must & $71.91 \%$ & 4 \\
\hline \multirow{6}{*}{6} & \multirow{6}{*}{$\begin{array}{c}\text { What is the most common } \\
\text { way to travel during your } \\
\text { studies? }\end{array}$} & Car & $4.21 \%$ & \# \\
\hline & & Bus & $62.28 \%$ & $\#$ \\
\hline & & Bicycle & $5.97 \%$ & \# \\
\hline & & Walk & $21.85 \%$ & \# \\
\hline & & Taxi & $1.90 \%$ & \# \\
\hline & & Motorcycle & $3.80 \%$ & $\#$ \\
\hline \multirow{4}{*}{7} & \multirow{4}{*}{$\begin{array}{l}\text { Would you feel guilty if you } \\
\text { found yourself wasting } \\
\text { water, electricity, paper, etc? }\end{array}$} & Never & $0.81 \%$ & \# \\
\hline & & Rarely & $13.43 \%$ & \# \\
\hline & & Sometimes & $51.29 \%$ & $\#$ \\
\hline & & Often & $34.46 \%$ & $\#$ \\
\hline \multirow{4}{*}{8} & \multirow{4}{*}{$\begin{array}{l}\text { What kind of measures } \\
\text { should be taken to promote } \\
\text { energy-saving? }\end{array}$} & $\begin{array}{l}\text { Legislation and strict } \\
\text { enforcement }\end{array}$ & $22.16 \%$ & $\#$ \\
\hline & & $\begin{array}{c}\text { Incentive and } \\
\text { punishment mechanisms }\end{array}$ & $34.36 \%$ & $\#$ \\
\hline & & $\begin{array}{l}\text { Strengthen education } \\
\text { and publicity }\end{array}$ & $38.59 \%$ & $\#$ \\
\hline & & Others & $4.90 \%$ & $\#$ \\
\hline
\end{tabular}

\# represents no description.

In Table 6, we also observe that $77.75 \%$ of students turned off the lights when they left their dormitory or classroom, and only $0.95 \%$ of students have never done so. In daily life, $82.63 \%$ of students turned off the air conditioner when going out, and $61.47 \%$ of the students turned off the computer when going out. During the holiday period, $71.91 \%$ of students would cut off the dormitory power. Meanwhile, $85.75 \%$ of the respondents felt guilty, to varying degrees, when they found themselves wasting water, electricity, and other energy. In addition, respondents also proposed a series of measures 
to promote energy-saving behaviors and environmental protection. Among them, the most important is to strengthen education and publicity about saving energy (38.59\%), followed by the establishment of incentive and punishment mechanisms (34.36\%), and legislation and strict enforcement $(22.16 \%)$.

The energy-saving behaviors and attitudes were nearly the same in all five universities. For example, switching off the lights when going out, which is easy to execute, was the first step that people took to move toward more energy-saving behaviors and occurred at nearly the same level in each university. However, there were some exceptions to this similarity. For example, more students at the University of Macau and the University of Science and Technology of Macau feel guilty when they find themselves wasting water, electricity, and paper, etc.

\subsection{Correlation Analysis}

In this study, SPSS 25 software was used to establish a multiple linear regression model, which was analyzed from five aspects of respondents' basic information, energy-saving knowledge, energy-saving education, energy-saving attitudes, and energy-saving behaviors. In Table 7, we observe that the $X_{11}$, $\mathrm{X}_{31}, \mathrm{X}_{32}, \mathrm{X}_{52}$, and $\mathrm{X}_{55}$ are positively correlated with energy-saving awareness, but not significantly. Similarly, $\mathrm{X}_{12}, \mathrm{X}_{13}, \mathrm{X}_{22}, \mathrm{X}_{23}$, and $\mathrm{X}_{53}$ were negatively correlated with energy-saving awareness of respondents, but not significantly. This indicates that these factors have a relatively small impact on respondents' awareness of saving energy.

Table 7. The correlation between energy-saving awareness and social characteristics.

\begin{tabular}{cccccc}
\hline Category & Variables & B value & Beta & $\mathbf{t}$ & Sig. \\
\hline \multirow{3}{*}{$X_{1}$} & $X_{11}$ & 0.001 & 0.001 & 0.039 & 0.969 \\
& $X_{12}$ & -0.007 & -0.021 & -0.562 & 0.574 \\
& $X_{13}$ & -0.007 & -0.006 & -0.161 & 0.872 \\
\hline \multirow{2}{*}{$X_{2}$} & $X_{21}$ & 0.096 & 0.098 & 2.569 & $0.010^{*}$ \\
& $X_{22}$ & -0.015 & -0.024 & -0.635 & 0.526 \\
& $X_{23}$ & -0.030 & -0.044 & -1.089 & 0.276 \\
\hline \multirow{2}{*}{$X_{3}$} & $X_{31}$ & 0.020 & 0.035 & 0.898 & 0.369 \\
& $X_{32}$ & 0.012 & 0.019 & 0.484 & 0.628 \\
\hline$X_{4}$ & $X_{41}$ & 0.122 & 0.150 & 3.587 & $0.000^{*}$ \\
\hline \multirow{4}{*}{$X_{5}$} & $X_{51}$ & 0.037 & 0.065 & 1.661 & $0.097^{*}$ \\
& $X_{52}$ & 0.021 & 0.025 & 0.658 & 0.511 \\
& $X_{53}$ & -0.043 & -0.043 & -1.101 & 0.271 \\
& $X_{54}$ & 0.050 & 0.082 & 2.112 & $0.035^{*}$ \\
& $X_{55}$ & 0.030 & 0.044 & 1.127 & 0.260 \\
\hline \multicolumn{5}{c}{ means the results are significant. } \\
\end{tabular}

In the $X_{2}$ category, $X_{21}$ is statistically significant at the level of $1 \%$. At the same time, $X_{21}$ is positively related to energy-saving awareness. This shows that if respondents have deeper understandings of the relationships between daily life and energy saving, they have higher energy awareness. In the $\mathrm{X}_{4}$ category, energy-saving awareness is positively correlated with $\mathrm{X}_{41}$ at the $1 \%$ significance level, indicating that with an increase of energy-saving education, the students' energy-saving awareness also continue to be improved. This also confirms that education is an effective way to improve energy-saving awareness. In the $X_{5}$ category, $X_{51}$ and $X_{54}$ was statistically significant at a $10 \%$ and $5 \%$ significance level, respectively. Moreover, energy-saving awareness is positively correlated with these two energy-saving behaviors, which supports that the improvement of energy-saving behaviors promote energy-saving awareness improvement. 


\section{Conclusions and Limitations}

\subsection{Conclusions}

Energy is essential and importance for the economic and social development, as well as the improvement of the quality of life in all countries. On the basis of the analyses of the relationships between energy-saving awareness and other factors among Macau university students, this study has gained an in-depth understanding of how to guide and motivate university students to adopt energy-saving behaviors.

Our study showed that the mean level of energy-saving behavior was nearly the same in all five universities. Meanwhile, most (75.98\%) of the respondents clearly realized that energy-saving behaviors and environmental protection are closely related to their study and life. In addition, more than half of the respondents indicated that, currently, the energy in Macau is not efficiently utilized. Therefore, relevant departments need to make more efforts to publicize energy-saving knowledge. At the same time, more attentions should be given to energy-saving behaviors and awareness. Previous studies [30] have shown that increased energy-saving awareness has a limited effect on behavior. However, this study found that energy-saving behaviors were positively correlated with energy-saving awareness at the significant levels of $10 \%$ and $5 \%$, respectively. In addition, Sardianou [31] concluded that consumers' beliefs regarding contributions to energy saving were key, and Ek and Soderholm [32] suggested that concern for the environment was the motivation. Our results indicate that energy-saving education is the basis of improving university students' energy-saving awareness. As a first step for energy-saving improvement, the government should carry out effective energy-saving education in secondary schools to obtain a wider range of future energy-saving population than university students. Secondly, the government also needs to disseminate behavioral knowledge, standardize social norms, and reward and punishment mechanisms, so that people can purchase and use more energy-saving equipment. In addition, governments and communities could provide more opportunities and places for university students to share their experiences.

Finally, the policies should emphasize the social norms of individual behavior constraints. The government should innovate the form and content of energy-saving publicity and education. When formulating energy-saving guidance policy, a comprehensive and reasonable energy-saving publicity and education system should be established from top to bottom. When implementing policy, the types and forms of energy-saving education and publicity need to be enriched, in order to adopt a variety of guidance policy with rich content, and strengthen the energy-saving awareness and knowledge of university students. On the basis of one-way publicity and education in the past, it should strengthen collective participation in energy-saving publicity and education activities, carry out energy-saving cultural activities through green groups and other nongovernmental organizations, and encourage university students to participate, experience and interact, and therefore build a campus energy-saving cultural atmosphere. To support university energy-saving education, energy-saving policies could include energy-saving scholarships or contests designed to motivate students to gain energy-saving knowledge. Meanwhile, shareholders could increase investment in energy-saving education and activities, aiming to instill an energy-saving culture to help students save energy more effectively. The results of our multiple regression analysis show that energy-saving awareness is positively correlated with the necessity for energy-saving education, which requires schools to strengthen energy-saving education for students. In addition, the government should enhancing external interventions based on situational factors because they have a significant moderating effect. At the same time, we can carry out extensive and reasonable publicity and guidance to cultivate conservation-oriented social ethics. Therefore, to encourage university students to implement positive energy consumption behaviors, it is necessary to give priority to energy-saving education and publicity guidance. 


\subsection{Limitations}

Due to the gap between university students' perception of behavior and their actual behavior, this study has some limitations. Future studies should be more scientific in order to quantity the energy-saving awareness through the behavior survey. In addition, the results of this study were obtained from questionnaires from five typical universities in Macau. The conclusions can provide a partial understanding of the energy-saving awareness of Macau university students, but it is difficult to represent the whole student group. Thus, the questionnaire survey could be expanded to a more representative sample (such as middle school students). Finally, this study focused on the correlation between energy-saving knowledge, energy-saving behavior, energy-saving attitude, and energy-saving awareness. In future studies, other factors and their interactions could be added. The sociodemographic factors are only used as control variables in this study, and their interactions with government policies are not addressed. Future research could examine these effects by improving the empirical study design.

Author Contributions: Conceptualization, Q.S. and S.Z.; methodology, Q.S. and S.Z..; software S.Z.; validation Q.S., S.Z. and C.W.; formal analysis, Q.S. and S.Z.; investigation, S.Z.; data curation, S.Z.; writing-original draft preparation, S.Z.; writing-review and editing, Q.S. and C.W.; funding acquisition, Q.S.

Funding: This research was funded by The Science and Technology Development Fund, Macau SAR., grant number (0027/2018/A).

Conflicts of Interest: The authors declare no conflict of interest.

\section{References}

1. Kaya, O.; Florkowski, W.J.; Us, A.; Klepacka, A.M. Renewable Energy Perception by Rural Residents of a Peripheral EU Region. Sustainability 2019, 11, 2075. [CrossRef]

2. European Commission. Energy 2020. A Strategy for Competitive, Sustainable and Secure Energy. 2010. Available online: http://library.arcticportal.org/1536/ (accessed on 18 July 2019).

3. International Energy Agency. World Energy Outlook 2017 Special Report Energy Access Outlook. 2017. Available online: https://webstore.iea.org/weo-2017-special-report-energy-access-outlook (accessed on 18 July 2019).

4. Nangia, R. Securing Asia's energy future with regional integration. Energy Policy 2019, 132, 1262-1273. [CrossRef]

5. EIA. International Energy Outlook. 2011. Available online: http://www.eia.gov/forecasts/ieo/ (accessed on 18 July 2019).

6. Song, Q.; Li, J. Greenhouse gas emissions from the usage of typical e-products by households: A case study of China. Clim. Chang. 2015, 132, 615-629. [CrossRef]

7. Kang, N.N.; Cho, S.H.; Kim, J.T. The energy-saving effects of apartment residents' awareness and behavior. Energy Build. 2012, 46, 112-122. [CrossRef]

8. Wang, Z.; Zhang, B.; Li, G. Determinants of energy-saving behavioral intention among residents in Beijing: Extending the theory of planned behavior. J. Renew. Sustain. Energy 2014, 6, 711-720. [CrossRef]

9. Poortinga, W.; Steg, L.; Vlek, C.; Wiersma, G. Household preferences for energy-saving measures: A conjoint analysis. J. Econ. Psychol. 2003, 24, 49-64. [CrossRef]

10. Yu, B.; Zhang, J.; Fujiwara, A. Evaluating the direct and indirect rebound effects in household energy consumption behavior: A case study of Beijing. Energy Policy 2013, 57, 441-453. [CrossRef]

11. Yue, T.; Long, R.; Chen, H. Factors influencing energy-saving behavior of urban households in Jiangsu Province. Energy Policy 2013, 62, 665-675. [CrossRef]

12. Ertz, M.; Karakas, F.; Sarigöllü, E. Exploring pro-environmental behaviors of consumers: An analysis of contextual factors, attitude, and behaviors. J. Bus. Res. 2016, 69, 3971-3980. [CrossRef]

13. Bin, L.; Sheng, H.M.; Wen, J.D.; Yan, X.; Guang, M.C. Integrating renewable energy education into national high educational system. In Proceedings of the ISES Solar World Congress 2007: Solar Energy and Human Settlement, Beijing, China, 18-21 September 2007. 
14. Hua, L.; Wang, S. Antecedents of Consumers' Intention to Purchase Energy-Efficient Appliances: An Empirical Study Based on the Technology Acceptance Model and Theory of Planned Behavior. Sustainability 2019, 11, 2994. [CrossRef]

15. DeWaters, J.E.; Powers, S.E. Energy literacy of secondary students in New York State (USA): A measure of knowledge, affect, and behavior. Energy Policy 2011, 39, 1699-1710. [CrossRef]

16. Gadenne, D.; Sharma, B.; Kerr, D.; Smith, T. The influence of consumers' environmental beliefs and attitudes on energy saving behaviours. Energy Policy 2011, 39, 7684-7694. [CrossRef]

17. Vringer, K.; Aalbers, T.; Blok, K. Household energy requirement and value patterns. Energy Policy 2007, 35, 553-566. [CrossRef]

18. Carrico, A.R.; Riemer, M. Motivating energy conservation in the workplace: An evaluation of the use of group-level feedback and peer education. J. Environ. Psychol. 2011, 31, 1-13. [CrossRef]

19. DSEC. Yearbook of Statistics 1999-2018. Macau Statistics and Census Service, Macau. 2018. Available online: http://www.dsec.gov.mo/Statistic.aspx?NodeGuid=d45bf8ce-2b35-45d9-ab3a-ed645e8af4bb (accessed on 23 July 2019).

20. Zhao, S.J.; Song, Q.B.; Duan, H.B.; Wen, Z.G.; Wang, C. Uncovering the lifecycle GHG emissions and its reduction opportunities from the urban buildings: A case study of Macau. Resour. Conserv. Recycl. 2019, 147, 214-226. [CrossRef]

21. Song, Q.; Duan, H.; Yu, D.; Li, J.; Wang, C.; Zuo, J. Characterizing the essential materials and energy performance of city buildings: A case study of Macau. J. Clean. Prod. 2018, 194, 263-276. [CrossRef]

22. Song, Q.; Li, J.; Duan, H.; Yu, D.; Wang, Z. Towards to sustainable energy-efficient city: A case study of Macau. Renew. Sustain. Energ Rev. 2017, 75, 504-514. [CrossRef]

23. Song, Q.; Wang, Z.; Li, J. Residents' behaviors, attitudes, and willingness to pay for recycling e-waste in Macau. J. Environ. Manag. 2012, 106, 8-16. [CrossRef] [PubMed]

24. Song, Q.; Wang, Z.; Li, J. Exploring residents' attitudes and willingness to pay for solid waste management in Macau. Environ. Sci. Pollut. Res. 2016, 23, 16456-16462. [CrossRef] [PubMed]

25. Yoo, S.H.; Kwak, S.Y. Willingness to pay for green electricity in Korea: A contingent valuation study. Energy Policy 2009, 37, 5408-5416. [CrossRef]

26. Song, Q.B.; Zhao, S.J.; Lam, I.; Zhu, L.C.; Yuan, W.Y.; Wang, C. Understanding residents and enterprises' perceptions, behaviors, and their willing to pay for resources recycling in Macau. Waste Manag. 2019, 95, 129-138. [CrossRef] [PubMed]

27. Sun, Y.; Jiang, L. A study about the influence of psychological factors on energy consumption behavior of urban residents. Consum. Econ. 2013, 2013, 77-79.

28. Hiller, C. Factors influencing residents' energy use-A study of energy-related behaviour in 57 Swedish homes. Energy Build. 2015, 87, 243-252. [CrossRef]

29. Sun, Y.; Song, J.B.; Song, D.R. An empirical study on influencing factors of resident's environmental behavior. Chin. J. Manag. 2012, 1, 144-150.

30. Wang, Z.; Zhang, B.; Yin, J.; Zhang, Y. Determinants and policy implications for household electricity-saving behaviour: Evidence from Beijing, China. Energy Policy 2011, 39, 3550-3557. [CrossRef]

31. Sardianou, E. Estimating energy conservation patterns of greek households. Energy Pol. 2007, 35, 3778-3791. [CrossRef]

32. Ek, K.; S?Derholm, P. The devil is in the details: household electricity saving behavior and the role of information. Energy Pol. 2010, 38, 1578-1587. [CrossRef]

(C) 2019 by the authors. Licensee MDPI, Basel, Switzerland. This article is an open access article distributed under the terms and conditions of the Creative Commons Attribution (CC BY) license (http://creativecommons.org/licenses/by/4.0/). 